\title{
The Possible Role of the Pituitary Gland and Uterine Tissue in the Production System of 13,14-Dihydroprostaglandin $\mathrm{F}_{2 a}$ in Rat Ovary*
}

\author{
Norihisa INAZU, Hiroshi KOGO and Yoshio AIZAWA \\ Department of Pharmacology, Tokyo College of Pharmacy, \\ 1432-1 Horinouchi, Hachioji, Tokyo 192-03, Japan
}

Accepted February 13, 1984

\begin{abstract}
In order to examine a possible role of the pituitary gland and uterine tissue in the formation of 13,14-dihydroprostaglandin $F_{2 \alpha}\left(13,14 \mathrm{H}_{2}-\mathrm{PGF}_{2 \alpha}\right)$ in rat ovary, hypophysectomized and hysterectomized rats were used. Gonadotropins stimulated the formation of $13,14 \mathrm{H}_{2}-\mathrm{PGF}_{2 \alpha}$ from prostaglandin $\mathrm{F}_{2 \alpha}\left(\mathrm{PGF}_{2 \alpha}\right)$ and 13,14-dihydro-15-keto-PGF $F_{2 \alpha}\left(15 \mathrm{KD}-\mathrm{PGF}_{2 \alpha}\right)$ in the ovarian homogenate of hypophysectomized and hysterectomized rats as well as in intact rats. Ovarian steroids, estradiol and progesterone, reduced the formation of $13,14 \mathrm{H}_{2}-\mathrm{PGF}_{2 \omega}$ in the ovarian homogenate of intact rats. However, in hysterectomized and hypophysectomized rats, its formation was not affected by ovarian steroids. On the other hand, when pregnant mare serum gonadotropin (PMS) and estradiol were simultaneously administered to intact and hypophysectomized rats, the formation of $13,14 \mathrm{H}_{2}$ $\mathrm{PGF}_{2 a}$ in the ovary showed a tendency to be increased as compared with that after treatment with PMS alone. These results not only suggest that the formation of $13,14 \mathrm{H}_{2}-\mathrm{PGF}_{2}$ in rat ovary is regulated by gonadotropins and ovarian steroids, but also that uterine tissue may take part in the process of its formation.
\end{abstract}

The catabolism of prostaglandin (PG) is initiated by 15-hydroxyprostaglandin dehydrogenase, which causes the oxidation of the 15-hydroxy group. This enzyme is widely distributed in the body (1) and plays an important role in the physiological inactivation of PG. The activity of $\Delta^{13}$-prostaglandin reductase and 15-ketoprostaglandin reductase varies from one species to another $(2,3)$. The existence of the enzymes 9ketoprostaglandin $E_{2}$ reductase and 9hydroxyprostaglandin $\mathrm{F}_{2 \infty}$ dehydrogenase has been reported for several animal tissues including rat kidney (2-4), rat testis (5), and human, pig and rat ovary (6). We have found that $\mathrm{PGF}_{2 \alpha}$ is metabolized to 13,14 -dihydro$\mathrm{PGF}_{2 \infty}\left(13,14 \mathrm{H}_{2}-\mathrm{PGF}_{2 \omega}\right)$ via 15-keto-PGF $\mathrm{F}_{2 \omega}$ (15K-PGF $F_{2 \alpha}$ ) and 13,14-dihydro-15-keto$\mathrm{PGF}_{2 \alpha}\left(15 \mathrm{KD}-\mathrm{PGF}_{2 \alpha}\right)$ in the ovarian homo-

* A part of this study has been reported at the 6th Regional Meeting (Kinki, Seinan area) of the Japanese Pharmacological Society, Yonago, November, 1982. genate of rats (7). The formation of $13,14 \mathrm{H}_{2}$ PG has been shown in guinea-pig lung (1), kidney (3), and liver (8,9), pig kidney (10) and human prostate (11). This compound has an appreciable contractile activity on several smooth muscle preparations, although the contractile activity is less than that of primary PG $(3,12,13)$. However, 15KD-PG has little contractile activity on smooth muscle preparations. On the other hand, we have recently reported that $13,14 \mathrm{H}_{2}-\mathrm{PGF}_{2 \alpha}$ in vitro markedly stimulated steroidogenesis in rat ovary (14), and Bydgeman et al. (15) have also observed that $13,14 \mathrm{H}_{2}-\mathrm{PGF}_{2 \alpha}$ enhanced contraction of the uterus in pregnant women in vivo. Thus, there is a great possibility that $13,14 \mathrm{H}_{2}-\mathrm{PGF}_{2 \infty}$ may possess a physiological function in the organs. Furthermore, we have recently reported that the formation of $13,14 \mathrm{H}_{2}-\mathrm{PGF}_{2 \alpha}$ in rat ovary was stimulated by gonadotropins and suggested that $13,14 \mathrm{H}_{2}-\mathrm{PGF}_{2 \alpha}$ might play an important role in ovarian function (16).

In the present investigation, we have 
assessed the effect of gonadotropins and ovarian steroids on the formation of $13,14 \mathrm{H}_{2}-$ $\mathrm{PGF}_{2 \alpha}$ in the ovary of hypophysectomized and hysterectomized rats, and we have suggested the possible roles of the pituitary gland and uterine tissue in the formation of $13,14 \mathrm{H}_{2}-\mathrm{PGF}_{2 \alpha \text {. }}$

\section{Materials and Methods}

Adult female rats of the Wistar strain, weighing about $200 \mathrm{~g}$, were housed under constant temperature $\left(24^{\circ} \mathrm{C}\right)$ and a lighting regimen of $12 \mathrm{hr}$ light and $12 \mathrm{hr}$ dark. Water and food were always available. The vaginal smears were examined every morning, and the rats exhibiting the regular 4-day estrous cycle were used for the experiments after they had completed at least two normal cycles.

Hypophysectomy was carried out at an appropriate stage in the estrous cycle by Koyama's external auditory canal method (17), and the hypophysectomized rats were used at $48 \mathrm{hr}$ after surgery. Hysterectomy was carried out on the day of diestrus, and the hysterectomized rats were used 10-14 days after surgery.

Pregnant mare serum gonadotropin (PMS, Teikoku Hormone MFG Co. Ltd.) and human chorionic gonadotropin (hCG, Teikoku Hormone MFG Co. Ltd.) were dissolved in $0.9 \%$ saline, and $50 \mathrm{IU}$ of PMS and/or $25 \mathrm{IU}$ of hCG were given s.c. to hypophysectomized rats at $48 \mathrm{hr}$ after surgery. PMS (50 IU/rat) was given s.c. to intact and hysterectomized rats on the first day of diestrus. Estradiol and progesterone were dissolved in sesame oil, and $20 \mu \mathrm{g}$ of estradiol and $1 \mathrm{mg}$ of progesterone were given s.c. to intact and hysterectomized rats on the first day of diestrus. Estradiol (20 $\mu \mathrm{g} / \mathrm{rat}$ ) was given s.c. to hypophysectomized rats at $48 \mathrm{hr}$ after surgery. Control rats were given s.c. vehicle alone.

Ovaries were removed at $24 \mathrm{hr}$ after treatment with each hormone and homogenized in $0.6 \mathrm{ml}$ of Krebs-Ringer bicarbonate buffer ( $\mathrm{pH} 7.4)$. The ovarian homogenate $(0.1 \mathrm{ml})$ was used for the measurement of ovarian protein content by Lowry's method (18). The ovarian homogenate $(0.3 \mathrm{ml})$ was incubated with $0.2 \mu \mathrm{Ci}(18 \mathrm{pmole})$ of [9${ }^{3} \mathrm{H}$ ]-prostaglandin $\mathrm{F}_{2 \infty}(10.9 \mathrm{Ci} / \mathrm{mmol}$, New
England Nuclear) or $0.2 \mu \mathrm{Ci}(2.5$ pmole) of $\left[5,6,8,9,11,12,14-{ }^{3} \mathrm{H}\right]-13,14$-dihydro-15ketoprostaglandin $\quad F_{2 \alpha} \quad(80 \quad \mathrm{Ci} / \mathrm{mmol}$, Amersham Int. plc) in a test tube (total, 0.5 $\mathrm{ml}$ ) containing $\beta$-nicotinamide adenine dinucleotide (NAD, final concentration $4 \mathrm{mM}$; Sigma Chemical Co.) at $37^{\circ} \mathrm{C}$ for $15 \mathrm{~min}$ in an atmosphere of $95 \% \quad \mathrm{O}_{2}-5 \% \quad \mathrm{CO}_{2}$. The reaction was stopped by the addition of $2 \mathrm{ml}$ of acidified alcohol (ethanol-hydrochloric acid, 2000:1), and PGF $F_{2 \infty}$ and its metabolites in the incubation mixture were extracted with $6 \mathrm{ml}$ of ethyl ether. The ether phase was evaporated under a stream of nitrogen gas, and the ether extract was dissolved in $50 \mu \mathrm{l}$ of chloroform-methanol (1:1) and applied on a silica-gel thin-layer plate and then developed in chloroform-methanol-acetic acid-water (90:9:1:0.65, v/v) (4). The radioactivity on the plate was located by scanning it with a thin-layer chromatogram scanner, and the spots corresponding to the authentic markers were visualized by brief exposure to iodine vapor. The zone of each component was scraped off and placed in a scintillation vial before addition of $10 \mathrm{ml}$ Aquasol-2 scintillator solvent (New England Nuclear) and counted by a liquid scintillation spectrometer.

The results were expressed as pmole of ${ }^{3} \mathrm{H}-13,14 \mathrm{H}_{2}-\mathrm{PGF}_{2 \infty}$ formed per ovary, since similar trends were obtained in terms of pmole per mg protein, and statistical significance was assigned to $P$ values of 0.05 or less by Student's $t$-test.

Authentic $\mathrm{PGF}_{2 \infty}, 15 \mathrm{~K}-\mathrm{PGF}_{2 \alpha}, 15 \mathrm{KD}$ $\mathrm{PGF}_{2 \infty}$ and $13,14 \mathrm{H}_{2}-\mathrm{PGF}_{2 \alpha}$ were generously provided by Dr. John E. Pike of Upjohn Company, Kalamazoo, Michigan, U.S.A.

\section{Results}

Effect of PMS and hCG on the formation of $13,14 \mathrm{H}_{2}-\mathrm{PGF}_{2 \alpha}$ from $\mathrm{PGF}_{2 \alpha}$ in the ovary of hypophysectomized rats: The formation of $13,14 \mathrm{H}_{2}-\mathrm{PGF}_{2 \alpha}$ from $\mathrm{PGF}_{2 \alpha}$ in the ovarian homogenate of hypophysectomized rats was investigated at $24 \mathrm{hr}$ after treatment with PMS and hCG (Fig. 1). PMS and hCG stimulated the formation of $13,14 \mathrm{H}_{2}-\mathrm{PGF}_{2 \alpha}$ : that is, its formation was increased by PMS to 2.4 fold of the control level and increased by hCG to 3.3 fold. Moreover, the simul- 


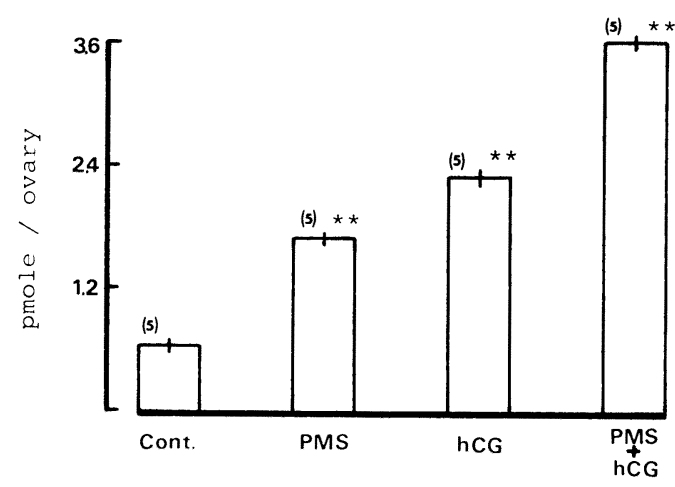

Fig. 1. Effect of PMS and hCG. on the formation of $13.14 \mathrm{H}_{2}-\mathrm{PGF}_{2^{\alpha}}$ from $\mathrm{PGF}_{2^{\alpha}}$ in the ovary of hypophysectomized rats. PMS (50 IU/rat) and hCG (25 IU/rat) were given s.c. to hypophysectomized rats at $48 \mathrm{hr}$ after hypophysectomy, and ovaries were removed at $24 \mathrm{hr}$ after treatment. The ovarian homogenate with ${ }^{3} \mathrm{H}-\mathrm{PGF}_{2 \alpha}$ was incubated at $37^{\circ} \mathrm{C}$ for $15 \mathrm{~min}$ in $95 \% \mathrm{O}_{2}-5 \% \mathrm{CO}_{2}$. Each column shows the mean \pm S.E., and each value in parenthesis shows the number of rats. ${ }^{*} P<0.01$, significantly different from the control.

taneous administration of PMS and hCG showed an additive effect (5.2 fold increase).

Effect of PMS on the formation of $13,14 \mathrm{H}_{2}$ $\mathrm{PGF}_{2 \alpha}$ in the ovary of hysterectomized rats: The effect of PMS on the formation of 13 . $14 \mathrm{H}_{2}-\mathrm{PGF}_{2 \alpha}$ from $\mathrm{PGF}_{2 \alpha}$ (Fig. 2A) and $15 K D-P G F_{2 \alpha}$ (Fig. 2B) in the ovarian homogenate of hysterectomized rats was examined. The formation of $13,14 \mathrm{H}_{2}-\mathrm{PGF}_{2 \alpha}$ from $\mathrm{PGF}_{2 \alpha}$ was increased to 2.6 fold of the control level, and that from 15KD-PGF $F_{2 \infty}$ to 1.7 fold of the control level.

PMS showed stimulatory action on the formation of $13,14 \mathrm{H}_{2}-\mathrm{PGF}_{2 \alpha}$ in both hypophysectomized and hysterectomized rats.

Effect of estradiol and progesterone on the formation of $13,14 \mathrm{H}_{2}-\mathrm{PGF}_{2 \alpha}$ in the ovary of intact and hysterectomized rats: Estradiol and progesterone were administered to intact and hysterectomized rats in order to study whether or not the formation of $13,14 \mathrm{H}_{2}$ $\mathrm{PGF}_{2 \alpha}$ was affected by exogenous ovarian steroids as well as gonadotropins. Administration of estradiol and progesterone significantly inhibited the formation of $13,14 \mathrm{H}_{2}$ $\mathrm{PGF}_{2 \omega}$ from $\mathrm{PGF}_{2 \alpha}$ in the ovary of intact rats (Fig. 3A). Its formation was markedly
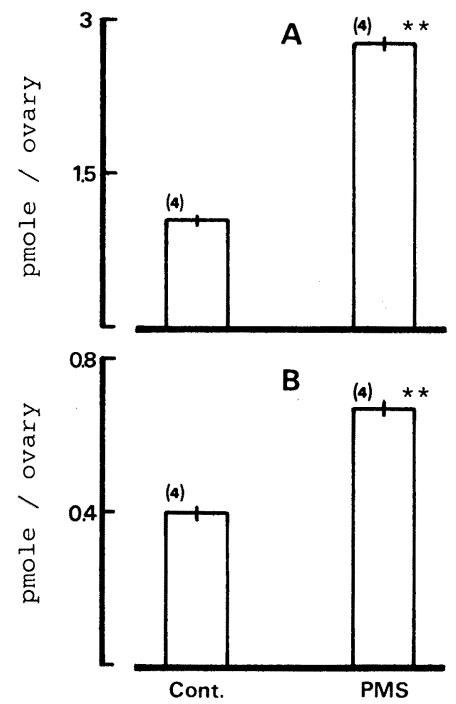

Fig. 2. Effect of PMS on the formation of $13,14 \mathrm{H}_{2}$ $\mathrm{PGF}_{2^{\alpha}}$ in the ovary of hysterectomized rats. A: Formation of $13,14 \mathrm{H}_{2}-\mathrm{PGF}_{2^{\alpha}}$ from $\mathrm{PGF}_{2^{\alpha}}, \mathrm{B}$ : Formation of $13,14 \mathrm{H}_{2}-\mathrm{PGF}_{2^{\alpha}}$ from 15KD-PGF $2^{\prime} \alpha$. PMS (50 IU/rat) was given s.c. to hysterectomized rats on the first day of diestrus, and ovaries were removed at $24 \mathrm{hr}$ after treatment. The ovarian homogenate with ${ }^{3} \mathrm{H}-\mathrm{PGF}_{2^{\alpha}}$ and ${ }^{3} \mathrm{H}-15 \mathrm{KD}-\mathrm{PGF}_{2^{\alpha}}$ was incubated as shown in Fig. 1. ${ }^{*} \mathrm{P}<0.01$. significantly different from the control.

decreased to $57.7 \%$ and $58.4 \%$ of the control level by estradiol and progesterone, respectively. The simultaneous injection of estradiol and progesterone also inhibited the formation, but there was no additive effect of these hormones on the formation. Furthermore, estradiol and progesterone showed inhibitory action on the formation of $13,14 \mathrm{H}_{2}$ $\mathrm{PGF}_{2 \infty}$ from $15 \mathrm{KD}-\mathrm{PGF}_{2 \infty}$ as well as that from $\mathrm{PGF}_{2 a}$ in the ovary of intact rats (Fig. 3B).

Then, the action of ovarian steroids on the formation of $13,14 \mathrm{H}_{2}-\mathrm{PGF}_{2 \infty}$ was also studied in the ovary of hysterectomized rats. The formation of $13,14 \mathrm{H}_{2}-\mathrm{PGF}_{2 \alpha}$ from both $P F_{2 \infty}$ and $15 K D-P G F_{2 \infty}$ was not influenced by ovarian steroids (Fig. $4 A$ and $B$ ), and this was quite different from the results with intact rats.

Interaction of PMS and estradiol in the formation of $13,14 \mathrm{H}_{2}-\mathrm{PGF}_{2 \infty}$ in the ovary of intact and hypophysectomized rats: The 
changes in the formation of $13,14 \mathrm{H}_{2}-\mathrm{PGF}_{2 \alpha}$ from $\mathrm{PGF}_{2 \alpha}$ in the ovarian homogenate were examined as compared with separate treatment of each drug when PMS, which increased the formation of $13,14 \mathrm{H}_{2}-\mathrm{PGF}_{2 \alpha}$,
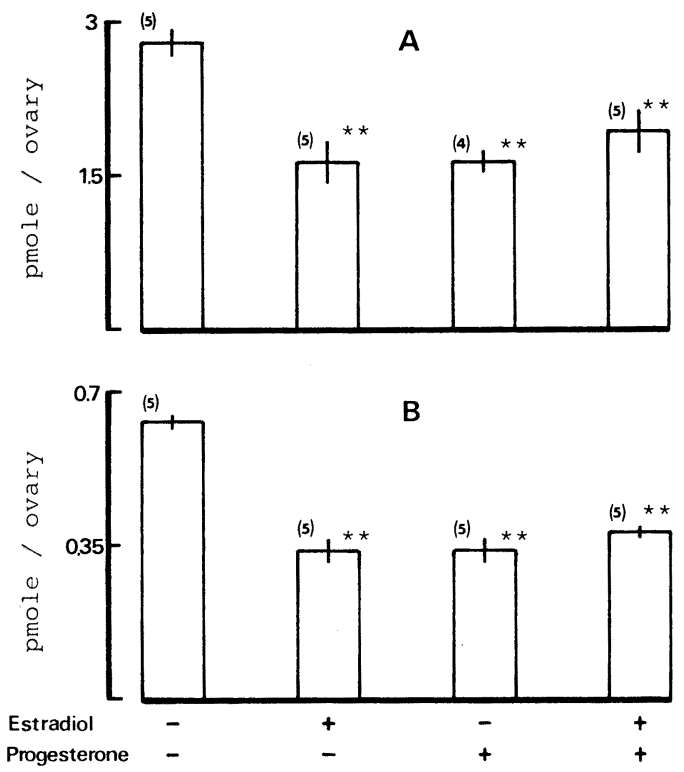

Fig. 3. Effect of estradiol and progesterone on the formation of $13,14 \mathrm{H}_{2}-\mathrm{PGF}_{2^{\alpha}}$ in the ovary of intact rats. A: Formation of $13,14 \mathrm{H}_{2}-\mathrm{PGF}_{2^{\alpha}}$ from $\mathrm{PGF}_{2^{\alpha}}$, B: Formation of $13,14 \mathrm{H}_{2}-\mathrm{PGF}_{2^{\alpha}}$ from $15 \mathrm{KD}-\mathrm{PGF}_{2^{\alpha} \text {. }}$. Estradiol $(20 \mu \mathrm{g} / \mathrm{rat})$ and progesterone $(1 \mathrm{mg} / \mathrm{rat})$ were given s.c. to intact rats on the first day of diestrus, and ovaries were removed at $24 \mathrm{hr}$ after treatment. The ovarian homogenate with ${ }^{3} \mathrm{H}-\mathrm{PGF}_{2^{\alpha}}$ and ${ }^{3} \mathrm{H}-15 \mathrm{KD}-\mathrm{PGF}_{2^{\alpha}}$ was incubated as shown in Fig. 1. ${ }^{* *} P<0.01$, significantly different from the control. and estradiol, which decreased its formation, were simultaneously administered to intact rats (Table 1). PMS alone facilitated the formation of $13,14 \mathrm{H}_{2}-\mathrm{PGF}_{2 \alpha}$ as described previously (16), and estradiol alone inhibited
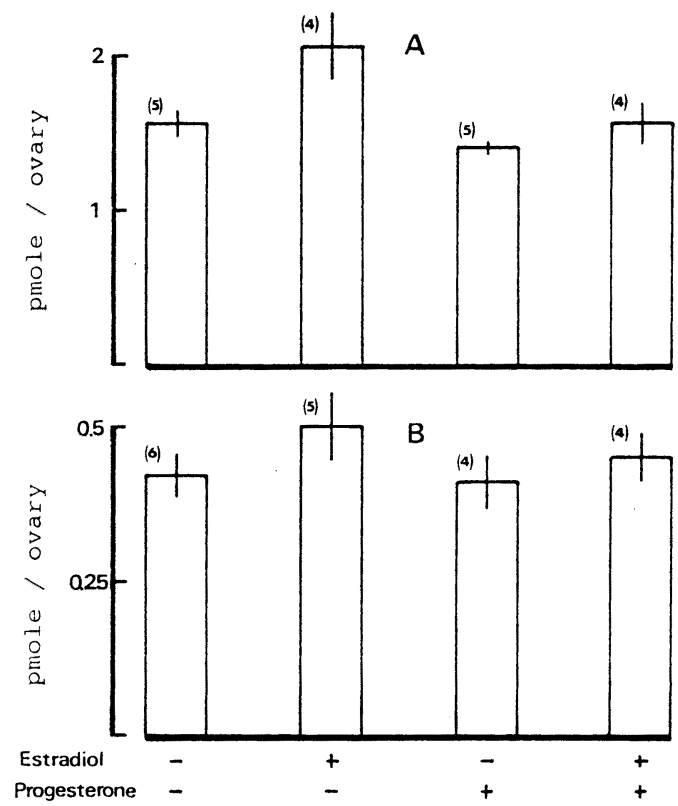

Fig. 4. Effect of estradiol and progesterone on the formation of $13,14 \mathrm{H}_{2}-\mathrm{PGF}_{2^{\alpha}}$ in the ovary of hysterectomized rats. A: Formation of $13,14 \mathrm{H}_{2}-\mathrm{PGF}_{2^{\alpha}}$ from $P G F_{2^{\alpha}}, B$ : Formation of $13,14 \mathrm{H}_{2}-\mathrm{PGF}_{2^{\alpha}}$ from $15 \mathrm{KD}-\mathrm{PGF}_{2^{\alpha}}$. Estradiol (20 $\mu \mathrm{g} / \mathrm{rat}$ ) and progesterone (1 mg/rat) were given s.c. to hysterectomized rats, and ovaries were removed at $24 \mathrm{hr}$ after treatment. The ovarian homogenate with ${ }^{3} \mathrm{H}$ $\mathrm{PGF}_{2^{\alpha}}$ and ${ }^{3} \mathrm{H}-15 \mathrm{KD}-\mathrm{PGF}_{2^{\alpha}}$ was incubated as shown in Fig. 1.

Table 1. Interaction of PMS and estradiol in the formation of $13,14 \mathrm{H}_{2}-\mathrm{PGF}_{2^{\alpha}}$ from $\mathrm{PGF} \mathrm{2}^{\alpha}$ in the ovary of intact rats

\begin{tabular}{cc}
\hline & $\begin{array}{c}13,14 \mathrm{H}_{2}-\mathrm{PGF}_{2^{\alpha}} \text { formed } \\
\text { pmole/ovary }\end{array}$ \\
\hline Control (5) & $2.79 \pm 0.117$ \\
PMS (7) & $4.63 \pm 0.646^{*}$ \\
Estradiol (4) & $1.61 \pm 0.214^{* *}$ \\
PMS $_{+}^{+}(6)$ & $5.21 \pm 0.716^{* *}$ \\
\hline Estradiol & \\
\hline
\end{tabular}

PMS (50 IU/rat) and estradiol (20 $\mu \mathrm{g} / \mathrm{rat}$ ) were given s.c. to intact rats on the first day of diestrus, and ovaries were removed at $24 \mathrm{hr}$ after treatment. Each value shows the mean \pm S.E. ${ }^{*} \mathrm{P}<0.05$ and ${ }^{* *} \mathrm{P}<$ 0.01 , significantly different from the control. 
Table 2. Interaction of PMS and estradiol in the formation of $13,14 \mathrm{H}_{2}-\mathrm{PGF}_{2^{\alpha}}$ from $15 K \mathrm{KD}-\mathrm{PGF} \mathrm{2}^{\alpha}$ in the ovary of hypophysectomized rats

\begin{tabular}{|c|c|c|}
\hline & & $\begin{array}{c}\text { 13,14 } \mathrm{H}_{2}-\mathrm{PGF}_{2^{\alpha}} \text { formed } \\
\text { pmole/ovary }\end{array}$ \\
\hline & Control (5) & $0.13 \pm 0.027$ \\
\hline & PMS (5) & $0.36 \pm 0.036^{* *}$ \\
\hline & Estradiol (4) & $0.17 \pm 0.019$ \\
\hline & 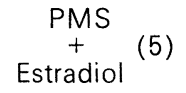 & $0.49 \pm 0.080^{* *}$ \\
\hline
\end{tabular}

PMS (50 IU/rat) and estradiol (20 $\mu \mathrm{g} / \mathrm{rat})$ were given s.c. to hypophysectomized rats at $48 \mathrm{hr}$ after surgery, and ovaries were removed at $24 \mathrm{hr}$ after treatment. Each value shows the mean \pm S.E. ${ }^{* *} \mathrm{P}<0.01$, significantly different from the control.

its formation as shown in Fig. 3. However, the simultaneous injection of PMS and estradiol tended to enhance the stimulatory action of PMS, but not significantly.

Similar experiments were carried out in hypophysectomized rats. Table 2 shows the formation of $13,14 \mathrm{H}_{2}-\mathrm{PGF}_{2 \infty}$ from $15 \mathrm{KD}$ $\mathrm{PGF}_{2 \infty}$ in the ovarian homogenate of hypophysectomized rats treated with PMS and estradiol. PMS not only increased the formation of $13,14 \mathrm{H}_{2}-\mathrm{PGF}_{2 \infty}$ from $P \mathrm{PF}_{2 \alpha}$ in hypophysectomized rats in Fig. 1 , but also increased that from 15KD-PGF $2 \alpha$ to 2.8 fold of the control level. Administration of estradiol to hypophysectomized rats, as well as that to hysterectomized rats shown in Fig. 4, exerted no change in the formation of $13,14 \mathrm{H}_{2}-$ $\mathrm{PGF}_{2 \alpha}$ in the ovarian homogenate. On the other hand, the simultaneous injection of PMS and estradiol increased the formation of $13,14 \mathrm{H}_{2}-\mathrm{PGF}_{2 \boldsymbol{\alpha}}$ to 3.8 fold of the control level. The increasing ratio by these hormones combined, as well as the results in Table 1 . was higher than that by PMS alone, although there is no significance between these two groups.

\section{Discussion}

In our previous reports $(16,19)$, the formation of $13,14 \mathrm{H}_{2}-\mathrm{PGF}_{2 \boldsymbol{w}}$ in the ovarian homogenate of intact rats was markedly increased by treatment with PMS and hCG, and we suggested that the interaction between the formation of $13,14 \mathrm{H}_{2}-\mathrm{PGF}_{2 \alpha}$ in the ovary and the gonadotropic action might play an important role in ovarian functions. In the present paper, hypophysectomized and hysterectomized rats were used for the experiments in order to investigate the role of the pituitary gland and uterine tissue in the formation of $13,14 \mathrm{H}_{2}-\mathrm{PGF}_{2 \alpha}$ in the rat ovarian homogenate. The formation of 13 , $14 \mathrm{H}_{2}-\mathrm{PGF}_{2 \infty}$ in rat ovary was decreased by hypophysectomy or hysterectomy, but in both hypophysectomized and hysterectomized rats, gonadotropins showed a significant stimulatory action on its formation from $P \mathrm{PF}_{2 \alpha}$ and $15 \mathrm{KD}-\mathrm{PG} \mathrm{F}_{2 \alpha}$. These results indicate that the $13,14 \mathrm{H}_{2}-\mathrm{PGF}_{2 \alpha}$ formation in rat ovary is facilitated by endogenous and exogenous gonadotropins, and they strongly suggested that the action of gonadotropins on ovarian functions may be closely involved in its formation. Indeed, we found that 13, $14 \mathrm{H}_{2}-\mathrm{PGF}_{2 \alpha}$ as well as $\mathrm{PGF}_{2 \alpha}$ stimulated ovarian steroidogenesis in vitro, though neither $15 \mathrm{~K}-\mathrm{PGF}_{2 \alpha}$ nor $15 \mathrm{KD}-\mathrm{PGF}_{2 \alpha}$ had any effect on it (14).

In this paper, the effect of ovarian steroids and a possible role of uterine tissue in the formation of $13,14 \mathrm{H}_{2}-\mathrm{PGF}_{2 \alpha}$ in the ovary were studied in intact and hysterectomized rats. The formation of $13,14 \mathrm{H}_{2}-\mathrm{PGF}_{2 \infty}$ in the ovarian homogenate was significantly inhibited when estradiol and/or progesterone were administered to intact rats, whereas in hysterectomized rats, neither of these hormones showed any inhibitory effect on its formation. Moreover, estradiol did not reduce the formation of $13,14 \mathrm{H}_{2}-\mathrm{PGF}_{2 \boldsymbol{\alpha}}$ in the ovarian homogenate of hypophysectomized rats. The formation of $13,14 \mathrm{H}_{2}-$ $\mathrm{PGF}_{2 \infty}$ in the ovary was decreased by hypophysectomy or hysterectomy as compared 
with that of intact rats, but its formation in hypophysectomized rats was significantly decreased, suggesting that the pituitary gland exerts a great influence on the production system of $13,14 \mathrm{H}_{2}-\mathrm{PGF}_{2 \infty}$ in the ovary. However, the result (Fig. 4B and Table 2) that the inhibitory effect of estradiol on its formation was not found in hypophysectomized and hysterectomized rats strongly suggests that the uterine tissue as well as the pituitary gland may also be closely involved in the action of estrogen. We (20) and $\mathrm{Ham}$ et al. (21) already reported that the PG content in the uterine tissue was significantly increased by estrogen, and Gordon and Sherwood (22) reported that $\mathrm{PGF}_{2 \infty}$ stimulated the relaxin release from the rat corpus luteum. Furthermore, Fazleabas et al. (23) reported that estrogen stimulated the secretion of a plasmin inhibitor from the uterus in pigs and suggested that the inhibitor might prevent a proteolytic cascade. These reports suggest the presence of a variety of modulatory substances in the uterus, and it is speculated that these substances may affect the ovarian function.

On the other hand, estradiol administered simultaneously with PMS did not inhibit the action of PMS on the formation of 13 , $14 \mathrm{H}_{2}-\mathrm{PGF}_{2 \infty}$ in the ovarian homogenate of intact and hypophysectomized rat and the simultaneous injection tended to increase it more potently than that by PMS alone (Tables 1 and 2). These observations suggest that under physiological conditions, estrogen may have a role in both the regulation of the gonadotropin release from the pituitary gland and the acceleration of $13,14 \mathrm{H}_{2}-\mathrm{PGF}_{2 \infty}$ formation in the ovary. Goldenberg et al. (24) reported that there were a marked enhancement in the number of follicles and a marked increase in ovarian weight when follicle stimulating hormone (FSH) and estrogen were given sequentially. Reiter et al. (25) observed that antisera to estradiol inhibited the follicular growth and the ovarian weight increase induced by exogenous gonadotropins in hypophysectomized immature female rats, and they suggested that the endogenous ovarian estrogen secretion induced by gonadotropin might play a role in the follicular response to $\mathrm{FSH}$. This hypothesis has also been suggested by the experiments of Harman et al. (26) and Nakano et al. (27), which showed the inhibitory effect of antiestrogen, colmiphene, on the follicular growth and response to gonadotropins. We observed that when PMS and estradiol were administered simultaneously, the ovarian weight was increased as compared with that after treatment with PMS alone, but not significantly (data not shown). In addition, in our previous report (16), the formation of $13,14 \mathrm{H}_{2}-\mathrm{PGF}_{2 \alpha}$ in rat ovarian homogenate increased with time after PMS treatment. These facts and hypothesis suggest that the formation of $13,14 \mathrm{H}_{2}$ $\mathrm{PGF}_{2 \infty}$ in rat ovary is accelerated with the growth of follicles and regulated by the interaction between gonadotropins and ovarian estrogen induced by gonadotropins, and uterine tissue, although no detailed interaction between gonadotropins and estrogen is apparent.

\section{References}

1 Änggård, E.: Studies on the analysis and metabolism of the prostaglandins. Ann. N.Y. Acad. Sci. 180, 200-217 (1971)

2 Lee, S.-C.: Prostaglandin metabolism. J. Biol. Chem. 249, 1369-1375 (1974)

3 Hoult, J.R.S. and Moore, P.K.: Pathways of prostaglandin $F_{2^{\alpha}}$ metabolism in mammalian kidneys. Br. J. Pharmacol. 61, 615-626 (1977)

4 Pace-Asciak, C.: Prostaglandin 9-hydroxydehydrogenase activity in the adult rat kidney. J. Biol. Chem. 250, 2789-2794 (1975)

5 Lin, Y. and Jarabak, J.: Isolation of two proteins with 9-ketoprostaglandin reductase and NADPlinked 15-hydroxyprostaglandin dehydrogenase activities and studies on their inhibition. Biochem. Biophys. Res. Commun. 81, 1227-1234 (1978)

6 Watson, J., Shepherd, T.S. and Dodson, K.S.: Prostaglandin E-2-9-ketoreductase in ovarian tissues J. Reprod. Fertil. 57, 489-496 (1979)

7 Aizawa, Y., Inazu, N. and Kogo, H.: Catabolism of prostaglandin $F_{2^{\alpha}}$ : Differences between ovarian and uterine tissues. Prostaglandins 20, 95-103 (1980)

8 Hamberg, M. and Israelsson, U.: Metabolism of prostaglandin $E_{2}$ in guinea pig liver. I. Identification of seven metabolites. J. Biol. Chem. 245, 5107-5114 (1970)

9 Hamberg, M. and Samuelsson, B.: Metabolism of prostaglandin $E_{2}$ in guinea pig liver. II. Pathways in the formation of the major 
metabolites. J. Biol. Chem. 246, 1073-1077 (1971)

10 Granström, E.: Metabolism of prostaglandin $F_{2^{\alpha}}$ in swine kidney. Biochim. Biophys. Acta 239, 120-125 (1971)

11 Cavanaugh, A.H., Farnsworth, W.E., Griezerstein, H.B. and Wojtowicz, C.: The influence of testosterone and lactogen on synthesis and metabolism of prostaglandir, $F_{2^{\alpha}}$ by the human prostate. Life Sci. 26, 29-34 (1980)

12 Crutchley, D.J. and Piper, P.J.: Comparative bioassay of prostaglandin $E_{2}$ and its three pulmonary metabolites. Br. J. Pharmacol. 54, 397-399 (1975)

13 Nakano, J.: Relationship between the chemical structure of prostaglandins and their vasoactivities in dogs. Br. J. Pharmacol. 44, 63-70 (1972)

14 Inazu, N., Kogo, H. and Aizawa, Y.: Effect of 13.14-dihydroprostaglandin $F_{2^{\alpha}}$ on steroid biosynthesis in rat ovary. Japan. J. Pharmacol. 31, 301-303 (1981)

15 Bydgeman, M., Green, K., Toppozada, M., Wiqvist, N. and Bergstrom, S.: The influence of prostaglandin metabolites on the uterine response to $P G F_{2^{\alpha}}$. A clinical and pharmacokinetic study. Life Sci. 14, 521-531 (1974)

16 Inazu, N., Kogo, H. and Aizawa, Y.: Stimulation of the formation of 13,14-dihydroprostaglandin $\mathrm{F}_{2^{\alpha}}$ by gonadotropin in rat ovary. Biochim. Biophys. Acta 750, 98-104 (1983)

17 Koyama, R.: A simple method of hypophysectomy in rats. Endocrinol. Japon. 9, 321-323 (1962)

18 Lowry, O.H., Rosebrough, N.J., Farr, A.L. and Randall, R.J.: Protein measurement with the Folin phenol reagent. J. Biol. Chem. 193, 265275 (1951)

19 Inazu, N., Kogo, H. and Aizawa, Y.: Effect of pregnant mare serum gonadotropin and estradiol on the formation of 13.14-dihydroprostaglandin $F_{2^{\alpha}}$ in rat ovary. J. Pharmacobiodyn. 4, 541-543 (1981)

20 Kogo, H., Yamada, K. and Aizawa, Y.: Effect of estradiol on prostaglandin metabolism in rat uterus. Prostaglandins 13, 785-794 (1977)

21 Ham, E.A., Cirillo, V.J., Zanetti, M.E. and Kuehl, F.A.: Estrogen-directed synthesis of specific prostaglandins in uterus. Proc. Natl. Acad. Sci. U.S.A. 72, 1420-1424 (1975)

22 Gordon, W.L. and Sherwood, O.D.: Evidence for role of prostaglandins in the antepartum release of relaxin in the pregnant rat. Biol. Reprod. 28, 154-160 (1983)

23 Fazleabas, A.T., Geisert, A.D., Bazer, F.W. and Roberts, R.M.: Relationship between release of plasminogen activator and estrogen by blastocysts and secretion of plasmin inhibitor by uterine endometrium in the pregnant pig. Biol. Reprod. 29, 225-238 (1983)

24 Goldenberg, R.L., Vaitukaitis, J.L. and Ross, T.: Estrogen and follicle stimulating hormone interactions on follicle growth in rats. Endocrinology 90, 1492-1498 (1972)

25 Reiter, E.D., Goldenberg, R.L., Vaitukaitis, J.L. and Ross, G.T.: Evidence for a role of estrogen in the ovarian augmentation reaction. Endocrinology 91, 1518-1522 (1972)

26 Harman, S.M., Louvet, J.-P. and Ross, G.T.: Inhibition of the ovarian augmentation reaction by a chemical antiestrogen. Endocrinology 96, 1119-1122 (1975)

27 Nakano, R., Nakayama, T. and Iwao, M.: Inhibition of ovarian follicle growth by a chemical antiestrogen. Horm. Res. 16, 230-236 (1982) 